doi: $10.2306 /$ scienceasia1513-1874.2013.39.150

\title{
Comparison of multiplex polymerase chain reaction and immunoassay to detect Salmonella spp., S. Typhimurium, and $S$. Enteritidis in Thai chicken meat
}

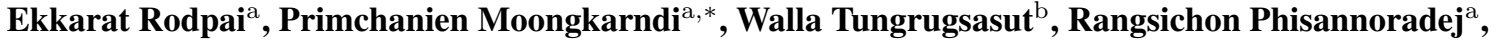 \\ Sasitorn Kanarat ${ }^{\mathrm{c}}$ \\ a Department of Microbiology, Faculty of Pharmacy, Mahidol University, Bangkok \\ b Department of Food Chemistry, Faculty of Pharmacy, Mahidol University, Bangkok \\ c Veterinary Public Health Laboratory, Ministry of Agriculture and Cooperatives, \\ Department of Livestock Development, Bangkok
}

${ }^{*}$ Corresponding author, e-mail: primchanien.moo@mahidol.ac.th

Received 13 Sep 2012

Accepted 5 Mar 2013

\begin{abstract}
The multiplex PCR (mPCR), enzyme-linked immunosorbent assay (ELISA) and immunomagnetic separation enzyme-linked immunosorbent assay (IMS-ELISA) were developed for the detection of Salmonella spp. and two specific serovars $S$. Typhimurium and $S$. Enteritidis. The detection limits of the mPCR without the pre-enriched step was at $10^{5} \mathrm{cfu} / \mathrm{ml}$, whereas developed immunoassays demonstrated positive results at $10^{5}, 10^{6}$, and $10^{7} \mathrm{cfu} / \mathrm{ml}$ by ELISA and at $10^{4}, 10^{4}$, and $10^{6} \mathrm{cfu} / \mathrm{ml}$ by IMS-ELISA for detecting Salmonella spp., S. Typhimurium, and $S$. Enteritidis, respectively. The mPCR did not produce any nonspecific amplified products when tested against other related species of bacteria. In this study, the developed IMS-ELISA gave more sensitivity but less specificity than the MPCR assay. The methods are useful for the rapid detection of salmonellae in naturally infected chicken meat in Thailand.
\end{abstract}

KEYWORDS: enzyme-linked immunosorbent assay (ELISA), immunomagnetic separation (IMS), food safety

\section{INTRODUCTION}

The importance of Salmonella spp. as a leading cause of foodborne diseases continues to be emphasized by national epidemiological reports from all over the world. Transmission to humans is mainly foodborne and results from eating undercooked meat, milk, eggs, or from cross-contamination of other foods which are eaten without cooking ${ }^{1,2}$.

More than 2500 serovars of Salmonella enterica have been identified; most have been described as the cause of human infections, especially $S$. enterica serovars Typhimurium and Enteritidis, which according to a WHO surveillance report have been the serovars most frequently isolated from cases of human food poisoning. Asian, American, European, and African health agencies have notified similar increases in such illnesses related to the consumption of eggs and poultry ${ }^{3-8}$.

Over the past decade, a number of studies have reported an increasing incidence of non-typhoid Salmonella bacteraemia ${ }^{9,10}$. Food safety in the exporting food industries needs a rapid method for detecting the contamination of Salmonella. Sev- eral countries, such as the European Union, USA, Japan, Korea, and Singapore, exercise strictly control and specifically forbid the contamination of $S$. Typhimurium and/or $S$. Enteritidis in food samples ${ }^{11}$. It is necessary for chicken exporting countries like Thailand to follow those requirements for chicken meat products.

Salmonella infection and spread can occur at any point during chicken production. Control measurements are needed to be enforced at each point of chicken meat and egg production. A number of rapid methods for the detection of Salmonella in foods has been developed and reported, including electrical techniques, nucleic acid analysis, and immunoassay ${ }^{12-16}$. These would reduce the time for testing by a few days. Molecular techniques such as polymerase chain reaction (PCR) can be used to solve that type of problems and increase sensitivity and specificity of pathogen detection. The simultaneous detection of several pathogens with a multiplex PCR (mPCR) approach would be relatively rapid and cost effective ${ }^{17-23}$. The enzyme-linked immunosorbent assay (ELISA) is the most prevalent antibody assay format used to detect pathogen food and it is still a favourable 
Table 1 List of target and non-target bacterial species used for determining the specificity of developed mPCR and immunoassay kits for Salmonella spp., S. Typhimurium, and $S$. Enteritidis.

\begin{tabular}{|c|c|c|c|c|c|c|c|c|c|}
\hline \multirow[t]{2}{*}{ Bacterial strains } & \multicolumn{3}{|c|}{ mPCR } & \multicolumn{3}{|c|}{ ELISA } & \multicolumn{3}{|c|}{ IMS-ELISA } \\
\hline & $\begin{array}{c}\text { Salmonella } \\
\text { spp. } \\
\text { (526 bp) }\end{array}$ & $\begin{array}{l}S . \text { Typhi- } \\
\text { murium } \\
(620 \mathrm{bp})\end{array}$ & $\begin{array}{l}S . \text { Ente- } \\
\text { ritidis } \\
(316 \mathrm{bp})\end{array}$ & $\begin{array}{l}\text { Salmo- } \\
\text { nella } \\
\text { spp. }\end{array}$ & $\begin{array}{l}S . \text { Typhi- } \\
\text { murium }\end{array}$ & $\begin{array}{l}S . \text { Ente- } \\
\text { ritidis }\end{array}$ & $\begin{array}{l}\text { Salmo- } \\
\text { nella } \\
\text { spp. }\end{array}$ & $\begin{array}{l}S . \text { Typhi- } \\
\text { murium }\end{array}$ & $\begin{array}{l}S . \text { Ente- } \\
\text { ritidis }\end{array}$ \\
\hline S. Typhimurium ATCC 13311 & + & + & - & + & + & - & + & + & - \\
\hline$S$. Typhimurium ATCC 14028 & + & + & - & + & + & - & + & + & - \\
\hline S. Typhimurium DMST 8536 & + & + & - & + & + & - & + & + & - \\
\hline S. Typhimurium DLDT 20713 & + & + & - & + & + & - & + & + & - \\
\hline$S$. Enteritidis ATCC 13076 & + & - & + & + & - & + & + & - & + \\
\hline$S$. Enteritidis DMST 8536 & + & - & + & + & - & + & + & - & + \\
\hline S. Enteritidis DLDT 24046 & + & - & + & + & - & + & + & - & + \\
\hline$S$. Enteritidis DLDT 24504 & + & - & + & + & - & + & + & - & + \\
\hline S. Anatum DLDT 24434 & + & - & - & + & - & - & + & - & - \\
\hline S. Anatum DLDT 24439 & + & - & - & + & - & - & + & - & - \\
\hline S. Blockley DMST 10639 & + & - & - & + & - & - & + & - & - \\
\hline S. Blockley DLDT 8937 & + & - & - & + & - & - & + & - & - \\
\hline$S$. Blockley DLDT 24442 & + & - & - & + & - & - & + & - & - \\
\hline$S$. Brunei DLDT 14794 & + & - & - & + & - & - & + & - & - \\
\hline$S$. Derby DLDT 24669 & + & - & - & + & - & - & + & - & - \\
\hline S. Hadar DLDT 24426 & + & - & - & + & - & - & + & - & - \\
\hline S. Hvittingfoss DLDT 1494 & + & - & - & + & - & - & + & - & - \\
\hline$S$. Lexington DLDT 12294 & + & - & - & + & - & - & + & - & - \\
\hline$S$. London DLDT 12494 & + & - & - & + & - & - & + & - & - \\
\hline S. Muenchen DLDT 24441 & + & - & - & + & - & - & + & - & - \\
\hline S. Panama DLDT 24437 & + & - & - & + & - & - & + & - & - \\
\hline S. Panama DLDT 24439 & + & - & - & + & - & - & + & - & - \\
\hline$S$. Paratyphi B Var Java DLDT 24305 & + & - & - & + & - & - & + & - & - \\
\hline S. Paratyphi B Var Java DLDT 24309 & + & - & - & + & - & - & + & - & - \\
\hline$S$. Paratyphi B Var Java DLDT 24311 & + & - & - & + & - & - & + & - & - \\
\hline$S$. Reading DLDT 14322 & + & - & - & + & - & - & + & - & - \\
\hline S. Saintpaul DLDT 23899 & + & - & - & + & - & - & + & - & - \\
\hline S. Saintpaul DLDT 23900 & + & - & - & + & - & - & + & - & - \\
\hline$S$. Stanley DLDT 24674 & + & - & - & + & - & - & + & - & - \\
\hline S. Typhi DMST 16122 & + & - & - & + & + & + & + & + & + \\
\hline$S$. Virchow DLDT 14596 & + & - & - & + & - & - & + & - & - \\
\hline$S$. Virchow DLDT 24428 & + & - & - & + & - & - & + & - & - \\
\hline S. Weltevreden DMST 10637 & + & - & - & + & - & - & + & - & - \\
\hline S. Weltevreden DLDT 8937 & + & - & - & + & - & - & + & - & - \\
\hline S. Weltevreden DLDT 14932 & + & - & - & + & - & - & + & - & - \\
\hline Campylobacter coli ATTC 43485 & - & - & - & - & - & - & - & - & - \\
\hline C. jejuni ATCC 33291 & - & - & - & - & - & - & - & - & - \\
\hline Citrobacter freundii ATTC 8090 & - & - & - & - & - & - & - & - & - \\
\hline Enterobacter aerogenes ATCC 13048 & - & - & - & - & - & - & - & - & - \\
\hline Enterococcus faecalis ATCC 29218 & - & - & - & - & - & - & - & - & - \\
\hline Escherichia coli ATCC 25922 & - & - & - & - & - & - & - & - & - \\
\hline E. coli ATCC 35218 & - & - & - & - & - & - & - & - & - \\
\hline Pseudomonas aeruginosa ATCC 27853 & - & - & - & - & - & - & - & - & - \\
\hline Staphylococcus aureus ATTC 25923 & - & - & - & - & - & - & - & - & - \\
\hline
\end{tabular}

technique of choice for practical use in most companies. The ELISA combined with immuno-magnetic separation (IMS), which uses magnetic beads conjugated with anti-Salmonella antibodies on their surface $^{24,25}$. The bead, when mixed with Salmonellacontaminated sample, will bind the organism on their surface via antibodies to eliminate the inhibitory effect of potential competition with other organisms. The Salmonella-bead complex can be pulled out of solution by a magnet which would concentrate the organisms left in the solution for further identification by immunoassay ${ }^{26-28}$.

In the present work, we reported the development of mPCR system, ELISA and IMS-ELISA and compared the sensitivity and specificity of these methods for the detection of Salmonella spp., S. Typhimurium and $S$. Enteritidis. The developed assays were also applied to detect these bacteria in raw chicken obtained from fresh markets and exporting companies in Thailand.

\section{MATERIALS AND METHODS}

\section{Bacterial strains}

All reference micro-organisms listed in Table 1 were obtained from the American Type Culture Collection (ATCC), the Culture Collection for Medical Microorganism, Department of Medical Sciences Thailand (DMST) and the fresh isolates from the Veterinary Public Health Laboratory, Department of Livestock Development Thailand (DLDT). The microorganisms were identified by conventional methods 
Table 2 PCR primers for Salmonella spp., S. Typhimurium, and $S$. Enteritidis in multiplex assay.

\begin{tabular}{|c|c|c|c|c|}
\hline Species amplified & Target gene & $\begin{array}{l}\text { Primer } \\
\text { name }\end{array}$ & Sequence $\left(5^{\prime}\right.$ to $\left.3^{\prime}\right)$ & $\begin{array}{l}\text { Size of PCR } \\
\text { amplicon (bp) }\end{array}$ \\
\hline$S$. Typhimurium & FliC $^{2}$ & $\begin{array}{l}\text { Typ04 } \\
\text { Fli15 }\end{array}$ & $\begin{array}{l}\text { ACT GGT AAA GAT GGC T } \\
\text { CGG TGT TGC CCA GGT TGG TAA T }\end{array}$ & 620 \\
\hline$S$. Enteritidis & Insert Element (IE) ${ }^{5}$ & $\begin{array}{l}\text { IE1L } \\
\text { IE1R }\end{array}$ & $\begin{array}{l}\text { AGT GCC ATA CTT TTA ATG AC } \\
\text { ACT ATG TCG ATA CGG TGG G }\end{array}$ & 316 \\
\hline Salmonella spp. & $\operatorname{fim} Y^{28}$ & $\begin{array}{l}\text { fim } Y 1 \\
\operatorname{fim} Y 2\end{array}$ & $\begin{array}{l}\text { GAG TTA CTG AAC CAA CAG CT } \\
\text { GCC GGT AAA CTA CAC GAT GA }\end{array}$ & 526 \\
\hline
\end{tabular}

and serotyping based on the antigenic structure of both somatic or cell wall $(\mathrm{O})$ antigens and flagellar $(\mathrm{H})$ antigens. Those 44 reference strains were 4 strains of Salmonella Typhimurium, 4 strains of $S$. Enteritidis, 27 strains of other Salmonella spp. and 9 of nonSalmonella spp. The micro-organisms were grown following standard methods for Salmonella and Enterobacteriaceae and identified by conventional microbiological methods as described in Bacteriological Analytical Manual (BAM) for Salmonella detection ${ }^{7}$.

\section{Polymerase chain reaction primers}

PCR primers were synthesizes at the Bioservice Unit (BSU), the National Science and Technology Development Agency, Bangkok. The three pairs of oligonucleotide primers, ranging from 18- to 24-mers, were selected from either published sequences ${ }^{29-31}$. Their corresponding gene targets and sizes of expected amplification products are shown in Table 2.

\section{DNA template for mPCR optimization}

Total genomic DNA from all Salmonellae and other bacterial strains listed was purified as described by Ausubel et $\mathrm{al}^{32}$ and used for mPCR optimization. Briefly, cells were suspended in $567 \mu \mathrm{l}$ of TE $(10 \mathrm{mM}$ Tris- $\mathrm{HCl} \mathrm{pH}$ 8.0, $1 \mathrm{mM}$ EDTA) buffer with $30 \mu \mathrm{l}$ of $10 \%(\mathrm{w} / \mathrm{v})$ sodium dodecyl sulphate and $3 \mu \mathrm{l}$ of $20 \mathrm{mg} / \mathrm{ml}$ proteinase K (Sigma, USA) and were lysed for $1 \mathrm{~h}$ at $37^{\circ} \mathrm{C}$. Then, $100 \mu \mathrm{l}$ of $5 \mathrm{M} \mathrm{NaCl}$ and $80 \mu \mathrm{l}$ of cetyltrimethylammonium bromide (CTAB)$\mathrm{NaCl}$ were added and the solution was incubated for $10 \mathrm{~min}$ at $65^{\circ} \mathrm{C}$. DNA was extracted with phenolchloroform-isoamyl alcohol followed by chloroformisoamyl alcohol. The concentration of purified DNA was then determined by Lambda II spectrophotometer (Milton Roy Spectronic 300, USA) at a wavelength of $260 \mathrm{~nm}$.

\section{Culture preparation for immunoassay and MPCR}

One millilitre of overnight pure bacterial culture was centrifuged at $8000 \mathrm{~g}$ for $5 \mathrm{~min}$ (Hettich, MIKRO 22R,
Denmark). The supernatant was removed and the packed cells were re-suspended with $1 \mathrm{ml}$ of $0.01 \mathrm{M}$ PBS pH 7.4. The sample was boiled for $10 \mathrm{~min}$, then immediately cooled on ice for $15 \mathrm{~min}$. For immunoassay, the heat lysed bacteria was reported to contain the target antigen and can be used to perform immunoassay. For mPCR detection, the heat lysed bacteria was further centrifuged at $6000 \mathrm{~g}$ for $5 \mathrm{~min}$ to remove cell debris. The lysed supernatant was collected and $5 \mu \mathrm{l}$ was used as the template ${ }^{33}$.

\section{Detection of microorganism by polymerase chain reaction}

The amplification reaction was performed in a volume of $25 \mu$ containing $5 \mu$ of DNA template from $10^{8} \mathrm{cfu} / \mathrm{ml}$ of cell lysate as a DNA template. This sample was added to a mixture consisting of $1 \mathrm{X}$ PCR buffer (10 mM TrisHCl, pH 8.8; $50 \mathrm{mM} \mathrm{KCl,} \mathrm{0.1 \%}$ Triton X-100); $2 \mathrm{mM} \mathrm{MgCl}_{2} ; 150 \mu \mathrm{M}$ each dNTP; $0.2 \mathrm{U}$ of $\mathrm{Taq}$ DNA polymerase (Promega, USA); $0.40 \mu \mathrm{M}$ each of Typ04, Fli15 primers $0.40 \mu \mathrm{M}$ each of IE1L, IE1R primers and $0.40 \mu \mathrm{M}$ each of fimY1, fim $Y 2$ primers. The PCR reaction was performed in a GeneAmp PCR System 240 Thermal Cycle (Perkin Elmer Cetus, USA). PCR products were analysed on a $1 \%$ agarose gel with $0.5 \times$ TBE $(44.5 \mathrm{mM}$ Tris base, $44.5 \mathrm{mM}$ Boric acid and $1 \mathrm{mM}$ EDTA) as the running buffer. A 100 bp standard DNA ladder (Bio-Rad) was included on each gel for base pair-size comparison. Gels were stained with $0.5 \mu \mathrm{g} / \mathrm{ml}$ ethidium bromide and visualized under UV light.

\section{Preparation of immuno-magnetic beads}

Each rabbit polyclonal anti-Salmonella (US Biological), mouse monoclonal anti Salmonella D group (US Biological), and mouse monoclonal anti$S$. Typhimurium (US Biological) were coated on magnetic beads (Dynabeads M-450 Tosylactivated: $4 \times 10^{8}$ beads/ml) (Dynal). Firstly, beads were washed 1 time with $0.1 \mathrm{M}$ PBS pH 7.4 and, the beads were concentrated using magnetic particle concentra- 
tors (MPC) (Dynal) for $2 \mathrm{~min}$. Then, each antibody was diluted with $0.1 \mathrm{M} \mathrm{PBS} \mathrm{pH} 7.4$ to the appropriate concentration. Each diluted antibody was added to magnetic beads and incubated at $4{ }^{\circ} \mathrm{C}$ overnight with gentle rotation. The non-specific binding sites were blocked by BSA at the final concentration $1 \%(\mathrm{w} / \mathrm{v})$ and incubated at $4{ }^{\circ} \mathrm{C}$ overnight with gentle rotation. After this process, the beads were concentrated by MPC and washed twice with $0.1 \%$ BSA/0.01 M PBS $\mathrm{pH}$ 7.4. Then, the tosyl group was blocked by adding $0.1 \%$ (w/v) BSA/0.2 M Tris $\mathrm{pH} 8.5$ and incubated at room temperature overnight. The coated beads were concentrated by MPC and washed once with $0.1 \%$ $\mathrm{BSA} / 0.01 \mathrm{M}$ PBS pH 7.4 and stored in $0.1 \%(\mathrm{w} / \mathrm{v})$ BSA/PBS pH 7.4 at $4{ }^{\circ} \mathrm{C}$.

\section{Detection of microorganism by IMS-ELISA and ELISA}

One millilitre of sample was added to $10 \mu$ of immuno-magnetic beads and incubated for $1 \mathrm{~h}$ at $37^{\circ} \mathrm{C}$ with gentle rotation. MPC was used to separate the complex of coated beads and Salmonella from the rest of sample and washed 3 times with $0.1 \%$ BSA/PBS pH 7.4. The secondary antibody labelled with horseradish peroxidase (rabbit polyclonal antiSalmonella spp.: Biodesign) was diluted with $0.01 \mathrm{M}$ PBS pH 7.4 and incubated at room temperature with gentle rotation for $1 \mathrm{~h}$. Then, $o$-phenylenediamine; OPD (Dako) was added and incubated at room temperature for 5-30 min until yellow colour was observed. Then, $100 \mu \mathrm{l} 1 \mathrm{~N} \mathrm{H}_{2} \mathrm{SO}_{4}$ was added to stop the colour reaction between the enzyme and the substrate. The absorbance was measured at the wavelength of $450 \mathrm{~nm}$ using ELISA plate reader (Molecular Devices, Thermomax). The ELISA method was also performed the same as IMS-ELISA, only without using immunomagnetic beads to remove the excess of solution.

\section{Determination the specificity of developed MPCR, ELISA and IMS-ELISA}

The overnight cultures of various reference strains of Salmonella and other bacterial control strains were adjusted to a cell density of $10^{8} \mathrm{cfu} / \mathrm{ml}(\mathrm{OD} 600 \mathrm{~nm}$ was 0.131 for Salmonella) (Pharmacia Biotech, Novaspec II, Sweden). The samples were prepared as described above and were tested by developed mPCR, ELISA, and IMS-ELISA.

\section{Determination the detection limit of developed MPCR, ELISA and IMS-ELISA}

The suspension of each strain of Salmonella grown overnight at $37^{\circ} \mathrm{C}$ in buffered peptone water (BPW) (Difco, USA) was adjusted to the cell density of
$10^{8} \mathrm{cfu} / \mathrm{ml}$. Each sample was 10 -fold diluted to a cell density of $10^{8}$ to $1 \mathrm{cfu} / \mathrm{ml}$. The samples prepared as described above were tested by using developed mPCR, ELISA and IMS-ELISA to determine the sensitivity of each technique.

\section{Detection by immunoassay after enrichment step}

To observe the earliest incubation time to detect microorganisms present initially at $1 \mathrm{cfu} / \mathrm{ml}$ using the developed immunoassay kits, each sample containing $1 \mathrm{cfu} / \mathrm{ml}$ of reference strain of $S$. Typhimurium and $S$. Enteritidis, was incubated in BPW at $37^{\circ} \mathrm{C}$. The samples were prepared as described above and were tested by using developed mPCR and immunoassay at $0,4,6$, and $8 \mathrm{~h}$.

\section{Determination the contamination in chicken samples}

The 44 chicken meat samples obtaining from industrial companies (24 samples) and fresh markets (20 samples) in Thailand were surveyed for Salmonella contamination. Two samples from raw meat previously identified by microbiological methods free from Salmonella spp. contamination were also used as control. They were spiked with a mixture of $S$. Typhimurium and $S$. Enteritidis at $10^{2} \mathrm{cfu} / \mathrm{ml}$ before the enrichment step as positive controls for the detection of the targeted micro-organism in meat samples. The identification was performed according to the standard protocol for Salmonella detection in meat recommended by the Bacteriological Analytical Manual $^{7}$ with some modifications. Briefly, all of the samples were treated as follows: a $25 \mathrm{~g}$ of sample was chopped and homogenized with $100 \mathrm{ml}$ of BPW in a stomacher (Stomacher 400, UK) for $30 \mathrm{~s}$ and incubated at $37^{\circ} \mathrm{C}$ overnight. The samples were prepared by lysing cells according to the previous methods for mPCR and immunoassay. All of the samples were paralleled identified with a commercial ELISA diagnostic kit (TECRA Salmonella Visual Immunoassay; 3 M Microbiology, Australia) which was the reference method given in the U.S. Food and Drug Administration's Bacteriological Analytical Manual (BAM 7th Ed.).

\section{RESULTS}

\section{Specificity}

The developed mPCR, ELISA and IMS-ELISA provided specific detection for Salmonella spp., and serovars $S$. Typhimurium and $S$. Enteritidis. The PCR products were obtained clearly distinguished by agarose gel electrophoresis (Fig. 1). 


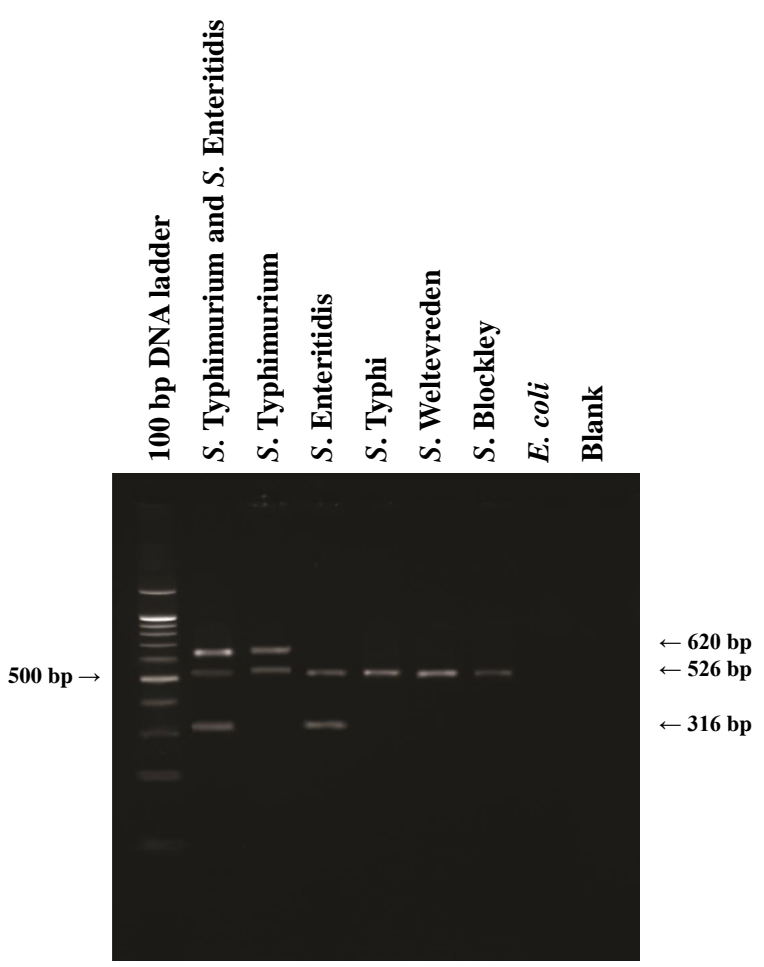

Fig. 1 Specificity of mPCR. PCR reactions were performed with a DNA template from different Salmonella serotypes and $E$. coli; each sample contains $10^{8} \mathrm{cfu} / \mathrm{ml}$ of reference strain microorganism. M: 100 bp DNA ladder; Lane 1: mixed culture of $S$. Typhimurium ATCC13311 and $S$. Enteritidis DMST8536; Lane 2: $S$. Typhimurium ATCC13311; Lane 3: $S$. Enteritidis DMST8536; Lane 4: $S$. Typhi DMST16122; Lane 5: S. Weltevreden DMST10637; Lane 6: S. Blockley DMST10639; Lane 7: E. coli DMST7948 (negative control); and Lane 8: blank.

\section{Detection limit}

The detection of the serial dilutions of boiled lysate of Salmonella at exact numbers of bacterial cells were performed and subjected to mPCR, ELISA, and IMSELISA. The lowest cell density at $10^{5} \mathrm{cfu} / \mathrm{ml}$ could be detected by the developed mPCR (Fig. 2). Whereas, IMS-ELISA gave the sensitivity at $10^{4}, 10^{4}$, and $10^{7} \mathrm{cfu} / \mathrm{ml}$ for detection of Salmonella spp., S. Typhimurium and $S$. Enteritidis, respectively (Fig. 3) and using ELISA at $10^{6} \mathrm{cfu} / \mathrm{ml}$ for all Salmonella tested.

\section{Detection the contamination in chicken samples}

The developed methods were applied to survey the contamination of Salmonella spp., S. Typhimurium and $S$. Enteritidis in 44 chicken meats sampling from Thai industrial meat products and fresh markets. The mPCR could identify 1 sample as, $S$. Enteritidis,

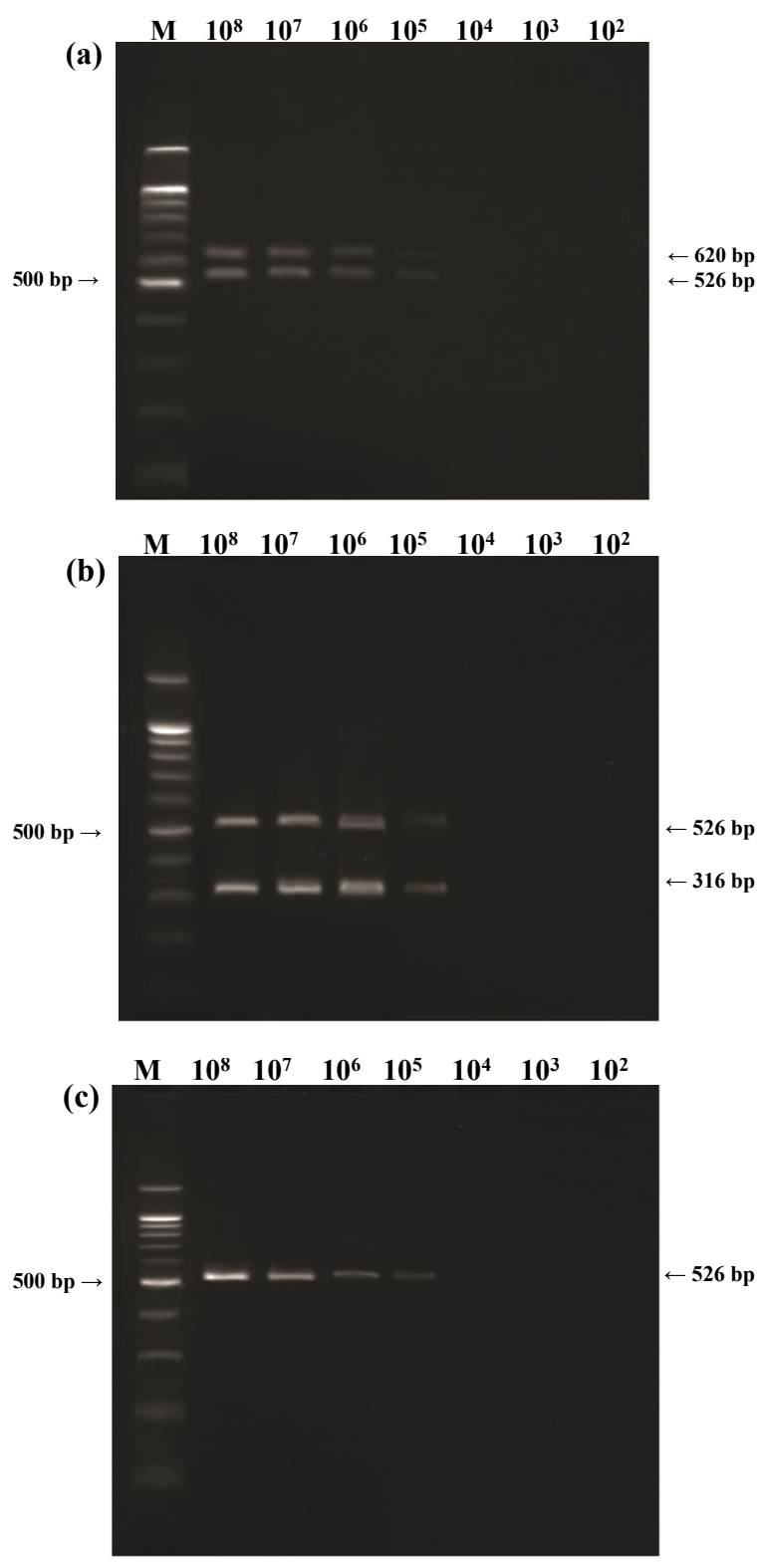

Fig. 2 Sensitivity of each primer pair in $\mathrm{mPCR}$ reaction: (a) gel A detected $S$. Typhimurium using Typ04, Fli15 primer, (b) gel B detected $S$. Enteritidis using IE1L, IE1R, and (c) gel C detected S. Typhi using fimY1, fimY2. PCR reactions were performed with each DNA template from serial dilutions at $10^{8}, 10^{7}, 10^{6}, 10^{5}, 10^{4}, 10^{3}$, and $10^{2} \mathrm{cfu} / \mathrm{ml}$ without pre-enrichment step.

which gave the positive PCR product of Salmonella spp. and $S$. Enteritidis. Whereas both developed immunoassay procedures could identify 2 samples contaminated with Salmonella. One sample was contaminated with $S$. Enteritidis which was the same 

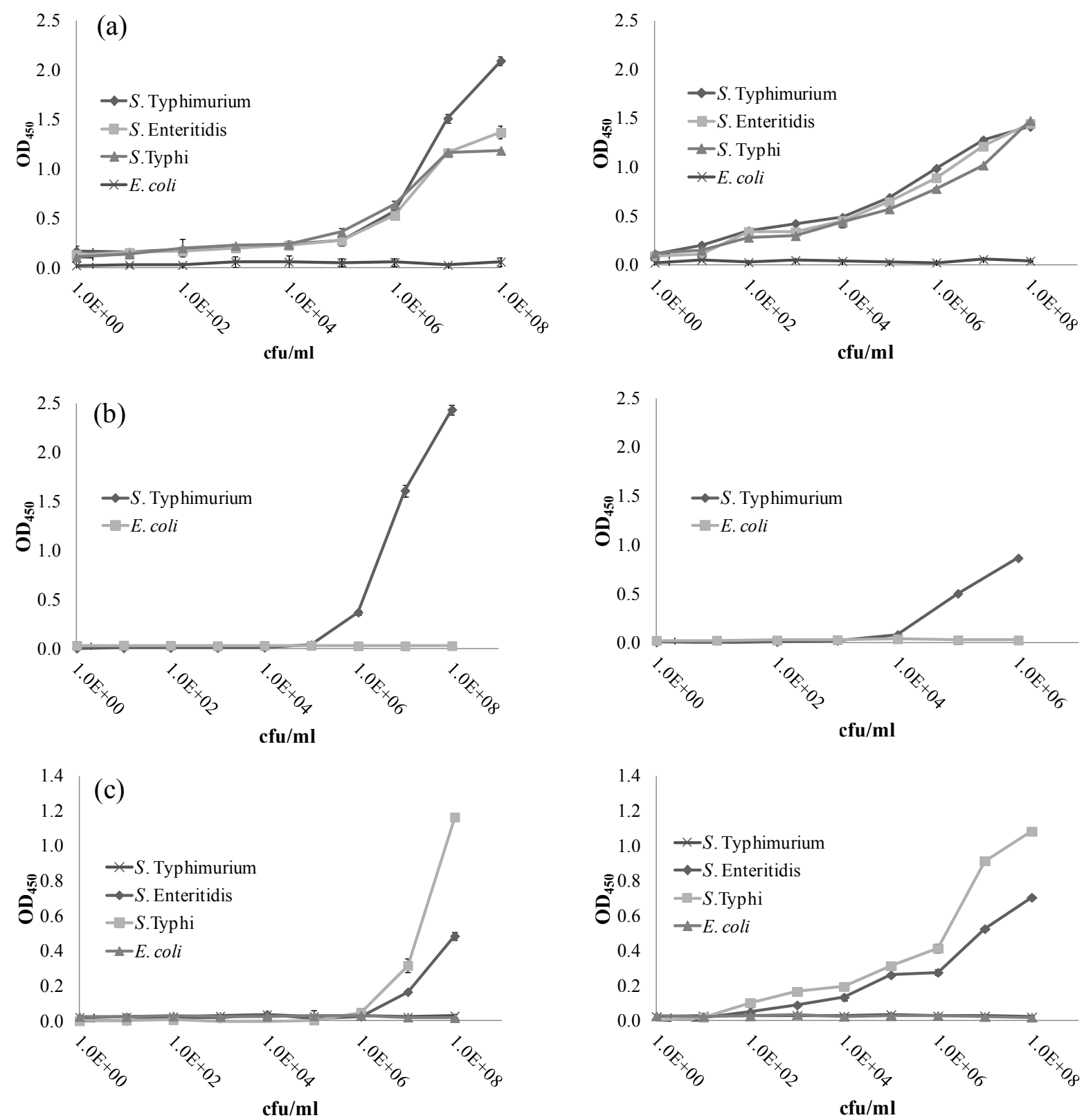

Fig. 3 Sensitivity of the developed immunoassays. Left panels: ELISA method, right panels: IMS-ELISA method. (a) Salmonella spp., (b) $S$. Typhimurium, (c) $S$. Enteritidis. All samples were enumerated exactly identified numbers of organisms at various concentrations varying from $1-10^{8} \mathrm{cfu} / \mathrm{ml}$ and applied to each well at $100 \mu \mathrm{l}$.

sample detected by mPCR and other sample was contaminated with Salmonella spp. but not serovars $S$. Typhimurium or $S$. Enteritidis. These 2 contaminated samples from 44 samples could be detected by TECRA Salmonella Visual Immunoassay, as the same samples as detected by using developed immunoassay. Those two contaminated samples were obtained from fresh markets. Samples from Thai exporting companies were found not contaminated by Salmonellae in our experiment. The results obtained from both methods were compatible.

\section{Detection by immunoassay after enrichment step}

The sample initially contained $1 \mathrm{cfu} / \mathrm{ml}$ of microorganism were incubated at $37^{\circ} \mathrm{C}$ and collected at 0 , 4,6 , and $8 \mathrm{~h}$ interval. The results showed that the developed immunoassay could begin to identify the positive results at $6 \mathrm{~h}$ (Fig. 4). 

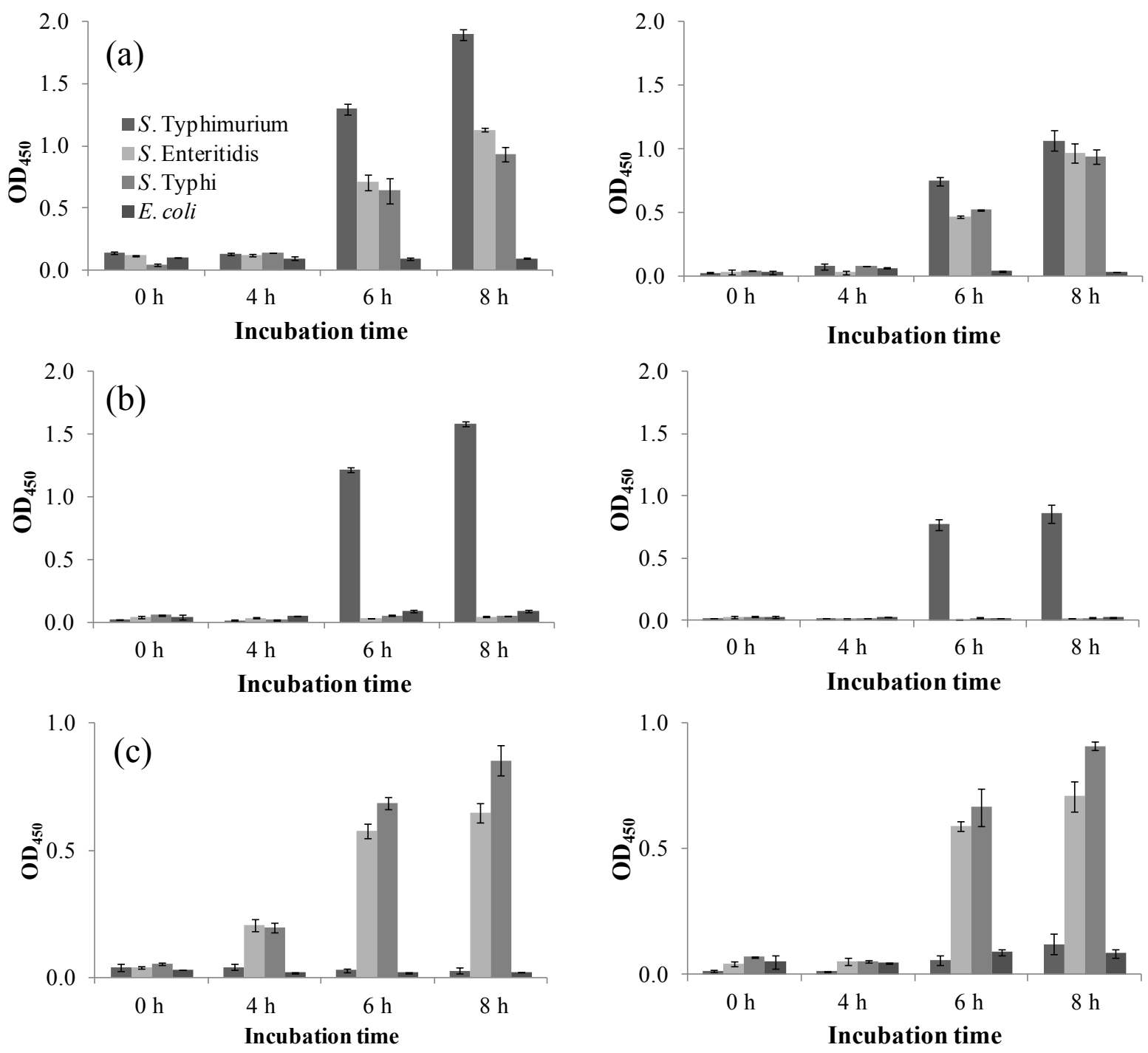

Fig. 4 The detection of Salmonella after enrichment of the developed immunoassays. Left panels: ELISA method, right panels: IMS-ELISA method. (a) Salmonella spp., (b) $S$. Typhimurium, and (c) $S$. Enteritidis. Sample was inoculated with $1 \mathrm{cfu} / \mathrm{ml}$ of $S$. Typhimurium, $S$. Enteritidis, and $S$. Typhi and incubated at $37^{\circ} \mathrm{C}$ for $0,4,6$, and $8 \mathrm{~h}$ before testing. Non-inoculated medium was used as a blank and E. coli as a negative control.

\section{DISCUSSION}

The aim of the present study was to compare the developed mPCR and immunoassay for the detection of Salmonella in chicken meat samples. In recent years, mPCR tests for Salmonella have been used to identify bacterial contamination in various samples, such as seafood, meat, fresh vegetables, and poultry, from non-selective enrichment with the limit of detection at $10^{3} \mathrm{cfu} / \mathrm{ml}^{14,34}$. For the ELISA methods, there were available commercial ELISAs for monitoring the infection status of swine, poultry, meat, and other foods for the presence of Salmonella spp. ${ }^{35}$, with the detection limit of $10^{5}-10^{6} \mathrm{cfu} / \mathrm{ml}^{36}$. Several attempts were made to lower the detection limits for Salmonella spp. based on ELISA method. The IMS-ELISA aiming to pre-concentrate cells from mixed cultures was reported to have a sensitivity limit of $10^{4}-10^{5} \mathrm{cfu} / \mathrm{ml}^{37}$.

The MPCR based assay was a rapid method and compatible with most methods used to ensure the safety of food products. Bacterial contaminations could be detected specifically depending on the selected primers and the process of determination was much shorter than standard microbiological methods. To develop the mPCR detection, the choice of the 
primer sets and optimization of the MPCR given suitable product sizes that could be separated by agarose gel electrophoresis, were initially performed. The $T m$ of each set of primers had to be considered in developing the system ${ }^{38}$ for optimization of mPCR. In this study, we selected 3 sets of primers resulted in 3 bands after amplification.

The mPCR in the study could differentiate Salmonella spp., $S$. Typhimurium and $S$. Enteritidis in a single tube reaction. The specific primers for the detection can be easily modified or designed to obtain specific reactivity to the target DNA from Salmonella in the sample. However, the suitable results, sensitivity, and specificity from mPCR have to be optimized and determined. For ELISA and IMS-ELISA methods, most of the assays are simple, easy to perform, and give quick results, but attention should be paid to the test quality concerning the characteristics of antibodies used for detection the target antigen of Salmonella in the sample. Since more than 2500 serovars of Salmonella enterica have been documented, it is at present too difficult to obtain the antibodies without cross reaction with very closely related serovars, even if monoclonal antibodies are used. The developed ELISA and IMS-ELISA in this study could not differentiate between $S$. Enteritidis and $S$. Typhi. Since, these 2 serovars were categorized in Salmonella group D, which had the similar O antigen, acted as the target of the antibody using in the immunoassays. However, most of $S$. Enteritidis is found in contaminated in poultry, then possibly transferring the infection to human, whereas $S$. Typhi is the serovar concerning transferring between human cases. The immunoassays require very highly specific and sensitive antibodies to develop the tests. The production and characterization of such antibodies would require substantial effort.

The developed IMS-ELISA gave the higher sensitivity $\left(10^{4} \mathrm{cfu} / \mathrm{ml}\right)$ to detect target the microorganism than mPCR $\left(10^{5} \mathrm{cfu} / \mathrm{ml}\right)$ (Fig. 2 and Fig. 3). Therefore, the sensitivity limit of the developed IMSELISA is comparable with that of the commerciallyavailable immunoassays for Salmonella spp. of $10^{5}$ $10^{7} \mathrm{cfu} / \mathrm{ml}^{37}$. The IMS-ELISA method uses a specific antibody coated on paramagnetic bead which help the antibody binding to antigen through the sample and to separate and concentrate the antigen by using the magnet, while in the MPCR method directly detection the DNA from the sample without included the concentration step in the technique.

Two specimens from fresh markets were found to be contaminated with Salmonella and $S$. Enteritidis by the developed immunoassays whereas mPCR could also identify one same sample contamination with $S$. Enteritidis but could not detect another one sample contamination. Commercial immunoassay kits control were able to identify the two sample contamination the same as our developed immunoassays, but the commercial kit could determine only as Salmonella spp. The specimens from industrial companies, however, were free from Salmonella contamination by all assays in the study.

The developed immunoassays can detect the contamination starting at $1 \mathrm{cfu} / \mathrm{ml}$ after $6 \mathrm{~h}$ enrichment. Generation time of $S$. Typhimurium and $S$. Enteritidis were 16.8 and $17.4 \mathrm{~min}$, respectively, (authors, personal communication). Therefore, after $6 \mathrm{~h}$ the organism number from $1 \mathrm{cfu} / \mathrm{ml}$ can be increased to the level that can detect by the assays (Fig. 4). Although the detection of bacteria in food by the prior enrichment of samples and increasing the time of analysis, but the enrichment brings benefits such as dilution of inhibitors, differentiation between viable and non-viable cells, and repairing of injured bacterial cells ${ }^{35,36,39-41}$. All processes for the developed mPCR, ELISA, and IMS-ELISA identification including pre-enrichment required only 16-24 h, which was less time-consuming than the microbiology-conventional methods. The conventional method needs at least 5-7 days to identify the serovar of Salmonella contamination.

We have compared the developed MPCR and immunoassay methods for determining Salmonella contamination in chicken. The data showed that the IMSELISA have more sensitivity but less specificity than mPCR assay. All the developed techniques are rapid, simple, specific and sensitive than the conventional methods. Salmonella serovars can be detected directly from chicken meat samples in Thailand. These mPCR, ELISA and IMS-ELISA assays would offer an effective alternative to conventional identification and differentiation of the $S$. Typhimurium, $S$. Enteritidis, and Salmonella spp. contamination. It would be beneficial to apply in industrial and governmental laboratories for food safety control and for consumer protection.

Acknowledgements: This study was supported by the Thailand Research Fund grant number RDG4720007. The authors wish to thank Dr Chainarong Kanthapanit for his valuable suggestions and discussions on the research.

\section{REFERENCES}

1. Agarwal A, Makker A, Goel SK (2004) Application of the PCR technique for a rapid, specific and sensitive 
detection of Salmonella spp. in foods. Mol Cell Probes 16, 243-50.

2. Alarcón B, García-Cañas V, Cifuentes A, González R, Aznar R (2004) Simultaneous and sensitive detection of three foodborne pathogens by multiplex PCR, capillary gel electrophoresis, and laser-induced fluorescence. J Agr Food Chem 52, 7180-6.

3. European Commission (2007) Commission Regulation (EC) No. 2073/2005 of 15 November 2005 on Microbiological Criteria for Foodstuffs. European Union.

4. Majtan T, Majtanova L, Timko J, Majtan V (2007) Oligonucleotide microarray for molecular characterization and genotyping of Salmonella spp. strains. $J$ Antimicrob Chemother 60, 937-46.

5. Nisbet DJ, Ziprin RL (2001) Salmonella in animals. In: Hui YH, Pierson MD, Gorham JR (eds) Foodborne Disease Handbook, Vol. 1. Marcel Dekker, New York, pp 265-84.

6. Oliveira SD, Santos LR, Schuch DMT, Silva AB, Salle CTP, Canal CW (2002) Detection and identification of salmonellas from poultry-related samples by PCR. Vet Microbiol 87, 25-35.

7. Andrews WH, Hammack TS (1998) Salmonella. In: Bacteriological Analytical Manual, 8th edn, Revision A, Chapter 5. US Food and Drug Administration.

8. WHO Global Salm-Surv (2006) Progress Report 2000 2005. http://www.who.int/salmsurv/en/.

9. CDC (2007) Salmonella Surveillance: Annual Summary, 2005. Centers for Disease Control and Prevention, US Department of Health and Human Services, Atlanta, Georgia, USA.

10. Voetsch AC, Van Gilder TJ, Angulo FJ, Farley MM, Shallow S, Marcus R, Cieslak PR, Deneen VC, et al (2004) FoodNet estimate of the burden of illness caused by nontyphoidal Salmonella infections in the United States. Clin Infect Dis 4, S127-34.

11. Department of Livestock Development, Ministry of Agriculture and Cooperatives (2008) Microbiological Standard Method, Thailand.

12. Harmon KM, Ransom GM, Wesley IV (1997) Differentiation of Campylobacter jejuni and Campylobacter coli by polymerase chain reaction. Mol Cell Probes 11, 195-200.

13. Jenikova G, Pazlarova J, Demnerova K (2000) Detection of Salmonella in food samples by the combination of immunomagnetic separation and PCR assay. Int Microbiol 3, 225-9.

14. Kim J, Demeke T, Clear RM, Patrick SK (2006) Simultaneous detection by PCR of Escherichia coli, Listeria monocytogenes and Salmonella typhimurium in artificially inoculated wheat grain. Int J Food Microbiol 111, 21-5.

15. Maciorowski KG, Pillai SD, Jones FT, Ricke SC (2005) Polymerase chain reaction detection of foodborne Salmonella spp. in animal feeds. Crit Rev Microbiol 31, 45-53.

16. Moongkarndi P, Rodpai E, Kanarat S (2011) Evaluation of an immunochromatographic assay for rapid detection of Salmonella enterica serovars Typhimurium and Enteritidis. J Vet Diagn Investig 23, 797-801.

17. Alvarez J, Sota M, Vivanco AB, Perales I, Cisterna R, Rementeria A, Garaizar J (2004) Development of a multiplex PCR technique for detection and epidemiological typing of Salmonella in human clinical samples. J Clin Microbiol 42, 1734-8.

18. Gilbert C, Winters D, O'Leary A, Slavik M (2003) Development of a triplex PCR assay for the specific detection of Campylobacter jejuni, Salmonella spp., and Escherichia coli 0157:H7. Mol Cell Probes 17, $135-8$.

19. Jamshidi A, Bassami MR, Afshari-Nic S (2009) Identification of Salmonella spp. and Salmonella typhimurium by a multiplex PCR-based assay from poultry carcasses in Mashhad- Iran. Iran J Vet Med 3, 43-8.

20. Kong RY, Lee SK, Law TW, Law SH, Wu RS (2002) Rapid detection of six types of bacterial pathogens in marine waters by multiplex PCR. Water Res 36, 2802-12.

21. Lee SH, Jung BY, Rayamahji N, Lee HS, Jeon WJ, Choi KS, Kweon CH, Yoo HS (2009) A multiplex real-time PCR for differential detection and quantification of Salmonella spp., Salmonella enterica serovar Typhimurium and Enteritidis in meats. J Vet Sci 10, 43-51.

22. Sambrook J, Russell DW (2001) Molecular Cloning: A Laboratory Manual. Cold Spring Harbor Laboratory, New York.

23. Szabó I, Scherer K, Roesler U, Appel B, Nöckler K, Hensel A (2008) Comparative examination and validation of ELISA test systems for Salmonella typhimurium diagnosis of slaughtering pigs. Int J Food Microbiol 124, 65-9.

24. Johnstone A, Thorpe R (1982) Immunochemistry in Practice. Blackwell Scientific Publications, Oxford 1982; pp 9-16.

25. Mansfield LP, Forsythe SJ (2000) The detection of Salmonella using a combined immunomagnetic separation and ELISA end-detection procedure. Lett Appl Microbiol 31, 279-83.

26. Lim DV, Simpson JM, Kearns EA, Kramer MF (2005) Current and developing technologies for monitoring agents of bioterrorism and biowarfare. Clin Microbiol Rev 18, 583-607.

27. Šafařík I, Šafaříková M (1999) Use of magnetic techniques for the isolation of cells. J Chrom B 722, 33-53.

28. Safarikova M, Safarik I (2001) The application of magnetic techniques in biosciences. Magn Electr Separ 10, 223-52.

29. Soumet C, Ermel G, Rose N, Rose V, Drouin P, Salvat G, Colin P (1999) Evaluation of multiplex PCR assay for simultaneous identification of Salmonella sp., Salmonella Enteritidis and Salmonella Typhimurium from environmental swabs of poultry houses. Lett Appl Microbiol 28, 113-7. 
30. Wang S-J, Yeh D-B (2002) Designing of polymerase chain reaction primers for the detection of Salmonella enteritidis in foods and faecal samples. Lett Appl Microbiol 34, 422-7.

31. Yeh K-S, Chen T-H, Liao C-W, Chang C-S, Lo H-C (2002) PCR amplification of Salmonella typhimurium fim $Y$ gene sequence to detect the Salmonella species. Int J Food Microbiol 78, 227-34.

32. Ausubel FM, Brent R, Kingston RE, Moore DD, Seidman JG, Smith JA, Struhl K (1987) Current Protocols in Molecular Biology. John Wiley and Sons, Inc., New York.

33. Phisannoradej R (2001) Polymerase chain reaction for detection of Campylobacter jejuni and bioassay for its toxins. MSc thesis, Mahidol Univ.

34. Kanki M, Sakata J, Taguchi M, Kumeda Y, Ishibashi M, Kawai T, Kawatsu K, Yamasaki W, et al (2009) Effect of sample preparation and bacterial concentration on Salmonella enterica detection in poultry meat using culture methods and PCR assaying of preenrichment broths. Food Microbiol 26, 1-3.

35. Vico JP, Engel B, Buist WG, Mainar-Jaime RC (2010) Evaluation of three commercial enzyme-linked immunosorbent assays for the detection of antibodies against Salmonella spp. in meat juice from finishing pigs in Spain. Zoonoses Publ Health 57, 107-14.

36. Kumar R, Surendran PK, Thampuran N (2009) Detection and characterization of virulence factors in lactose positive and lactose negative Salmonella serovars isolated from seafood. Food Contr 20, 376-80.

37. Mansfield LP, Forsythe SJ (2000) Detection of salmonellae in food. Rev Med Microbiol 11, 37-46.

38. Rychlik W (1993) Selection of primers for polymerase chain reaction. In: White BA (ed) PCR Protocols: Current Methods and Applications. Methods in Molecular Biology, Vol. 15, Humana Press, Totowa, NJ, pp 31-40.

39. Kumar S, Balakrishna K, Batra HV (2008) EnrichmentELISA for detection of Salmonella typhi from food and water samples. Biomed Environ Sci 21, 137-43.

40. Mandrell RE, Wachtel MR (1999) Novel detection techniques for human pathogens that contaminate poultry. Curr Opin Biotechnol 10, 273-8.

41. Trevanich S, Tiyapongpattana S, Miyamoto T (2010) Application of an optimized 18-h method involving one step culturing and single primer-based PCR assay for detection of Salmonella spp. in foods. Food Contr 21 , 93-8. 